\section{B. Gjelsvik svarer:}

Jeg takker for verdifulle kommentarer fra Emma Hansen. Å omtale pasienten i tredje person, som kanskje er Hansens viktigste innvending, følger av konteksten. Artikkelen er først og fremst rettet til leger og helsepersonell, ikke til pasienter. Det innebærer selvsagt ikke at jeg anser at pasienten, som er legegjerningens eneste mål, er uten intellektuell kapital eller skal «håndteres». Tvert om. Jeg synes det er problematisk at du kan lese innlegget mitt på denne måten, men din innvending er kanskje ikke ellers konkret rettet mot mine formuleringer.

Mitt anliggende er at legen og pasienten, så sant omstendighetene gjør det mulig, skal inngå i en likeverdig dialog der pasientens preferanser skal løftes fram, og valg skal være gjenstand for en reell forhandling. Dette blir altfor ofte oversett eller ikke vektlagt, og kan føre til at beslutninger som tas føles som overkjøring.

\section{Bjørn Gjelsvik}

bjorn.gjelsvik@medisin.uio.no

Bjørn Gjelsvik (f. 1949) er lege ved Institutt for helse og samfunn, Universitetet i Oslo.

Ingen oppgitte interessekonflikter.

\section{Re: Mens vi venter på Høie}

Det forundrer meg at legepresidenten skriver at Legeforeningen mener psykisk helse og rus er uegnede som piloter for Fritt behandlingsvalg (1). Er det ikke på tide at psykisk helse og rusfeltet blir tatt på alvor i spesialisthelsefamilien slik somatikken alltid blir? Og hvis noen raskt skulle få nyte godt av de tenkte positive sidene av Fritt behandlingsvalg, så burde det absolutt være disse pasientgruppene. Oversikt fra 2014 over ventetider og pasientrettigheter 2. tertial fra NPR og Helsedirektoratet viser at det særlig er ruspasienter som venter lengst på behandling (2). I rusfeltet er det også flest ikke-kommersielle private klinikker med avtaler, som i tillegg har ledig kapasitet for Fritt behandlingsvalg. Utmerket for pilot og klar til å bistå Høie for rusbehandling med kortere ventetid og mer brukerstyring.

\section{Erling Pedersen}

erpe@bergenclinics.no

Erling Pedersen er adm. direktør ved Stiftelsen Bergensklinikkene Interessekonflikt: Bergensklinikkene har avtale med Helse Vest om levering av tjenester innen rusbehandling/Tverrfaglig Spesialisert Behandling og møter 160 pasienter i behandling hver dag.

\section{Litteratur}

1. Gjessing H. Mens vi venter på Høie. Tidsskr Nor Legeforen 2014; 134: 2219.

2. Helsedirektoratet. Ventetider og pasientrettigheter 2. tertial 2014.

http://helsedirektoratet.no/publikasjoner/ventetider-og-pasientrettigheter2-tertial-2014/Sider/default.aspx (27.11.2014)

\section{H. Gjessing svarer:}

Fritt behandlingsvalg foreslås gradvis innført, først for rus og psykiatri. Disse pasientene er ofte sist ut i nye reformer, og det er derfor positivt at regjeringen forsøker å snu dette ved å prioritere dem først. Samtidig påpeker de fleste av Legeforeningens organisasjonsledd at dette er en ordning som passer best for avklarte tilstander, og at ordningen vil favorisere de ressurssterke som evner å orientere seg i helsetjenesten. Videre skal ordningen i første fase kun gjelde døgnbehandling, mens tendensen går bort fra dette $i$ både rus og psykisk helsevern. Innen disse fagfeltene satses det mer på lokal spesialisthelsetjeneste i form av dagbehandling og poliklinikk enn på langtids døgninstitusjoner langt fra pasientens hjemkommune. Det foreligger også risiko for at en redusert ventetid hos private leverandører vil omfatte de enkle og forutsigbare lidelsene. Vi har derfor kommet til at rus og psykiatri ikke egner seg for en første utprøving av ordningen.

\section{Hege Gjessing}

hege.gjessing@legeforeningen.no

Hege Gjessing (f.1972) er President i Den norske legeforening. Ingen oppgitte interessekonflikter.

\section{Re: En integrert forståelse av subjektive lidelser $\mathrm{i}$ klinisk praksis}

I sin kronikk i Tidsskriftet nr. 22/2014 definerer Tveråmo og medarbeidere subjektive lidelser som «..plager som pasienten rapporterer, der objektive funn ikke står i forhold til symptomene og der vi ikke har tilgjengelig teknologi som kan objektivere pasienten plager» (1). Her vil jeg hevde at forfatterne trår ut $i$ en begrepsmessig hengemyr hvor de blander sammen helt ulike fenomener. Dette er ikke et trivielt spørsmål om ordvalg, men gjelder hvordan vi som leger forstår viktige begreper og bruker dem overfor pasienter og allmennhet.

Hvilken mening har begrepet subjektive lidelser (eller symptomer)? Hva vil det si å objektivere pasientens plager? Det ligger nokså klart i definisjonen gjengitt ovenfor at når det finnes subjektiv lidelse, må det også finnes objektiv lidelse - hvorfor ellers ta med ordet subjektiv? Det kan også virke som om forfatterne mener at tilgang på bedre teknologi vil gjøre hittil uforklarte lidelser mindre subjektive (blir lidelsen mindre subjektiv hvis det gjøres objektive funn?). Men objektiv lidelse er et meningsløst, eller $\mathrm{i}$ beste fall forvirrende, begrep.

Lidelse (for eksempel smerte eller ekstrem tretthet) er en følelse, en opplevelse som en person har, ikke en objektivt erkjennbar «ting». Smerten er akkurat der og slik personen kjenner den (2). Lidelsen er akkurat slik pasienten selv opplever den. Den blir verken mer eller mindre reell ved påvisning av objektive forandringer i kroppen. Årsaken til lidelsen eller smerten, derimot, kan være noe helt annet enn det pasienten tror, og det samme gjelder meningen pasienten tillegger sin lidelse (3). Her gir resten av kronikken til Tveråmo og medarbeidere viktige bidrag til forståelse av sammenheng mellom symptomer og bakenforliggende mekanismer, og måter å tilnærme seg pasienter med «subjektive lidelser» på. Men definisjonen av subjektiv lidelse bidrar dessverre til å opprettholde en feilaktig oppfatning av at noen symptomer og lidelser er mer virkelige enn andre - nemlig de som vi kan påvise kroppslige årsaker til. En slik oppfatning blant leger er sannsynligvis en viktig årsak til den ulykkelige antagonismen mellom «skolemedisinen» og de store gruppene av pasienter med «medisinsk uforklarte lidelser».

\section{Per Brodal}

pabrodal@gmail.com

Per Brodal (f. 1940) er professor emeritus ved Institutt for medisinske basalfag, Universitetet i Oslo.

Ingen oppgitte interessekonflikter.

\section{Litteratur}

1. Tveråmo A, Johnsen IB, Meland E. En integrert forståelse av subjektive lidelser i klinisk praksis. Tidsskr Nor Legeforen 2014; 134: 2174-6.

2. Bennett MR, Hacker PMS. Philosophical foundations of neuroscience. Oxford: Blackwell Publishing, 2003.

3. Cassell E. The nature of healing. The modern practice of medicine. New York Oxford University Press, 2013. 